\title{
Peer assisted learning as a tool for facilitating social and academic integration
}

\section{Emmeline Byl}

Vrije Universiteit Brussel, UK

\section{Katrien Struyven}

Vrije Universiteit Brussel, UK

\section{Pieter Meurs}

Vrije Universiteit Brussel, UK

\section{Bieke Abelshausen}

Vrije Universiteit Brussel, UK

\section{Koen Lombaerts}

Vrije Universiteit Brussel, UK

\section{Nadine Engels}

Vrije Universiteit Brussel, UK

\section{Tom Vanwing}

Vrije Universiteit Brussel, UK

\section{Abstract}

Research into first-year students entering higher education shows that student integration into the academic community is a primary condition for student success. Peer support helps students settle into university life. This research explores the value of peer assisted learning (PAL) as a tool in an out-of-classroom context to increase the social and academic integration of first-year university students. Focus group interviews $(n=16)$ were conducted with first-year students ( $\mathrm{n}=93$ ). Using appreciative inquiry, as an innovative qualitative, participative research method, participants suggested that during the first semester of the academic year, peer mentoring and peer modelling especially are important tools. Informally organised peer tutoring stimulates students to participate and is shown to be helpful. This paper aims to prompt further discussion on the implications for 
practice, policy and future research of peer assisted learning programmes for student integration.

Keywords: peer support; peer learning; social integration; academic integration; transition into higher education; appreciative inquiry; first-year students.

\section{Introduction}

Initiatives to support university students in learning and personal development are expanding, as universities seek to improve retention and achievement rates (Brown et al., 2014). Research into first-year students entering higher education confirms that both social and academic integration are primary conditions for success (Borglum and Kubala, 2000; Tinto and Pusser, 2006). While the theoretical framework and terminology could benefit from an update, the seminal work of Tinto still remains a benchmark for understanding social and academic integration (Davidson and Wilson, 2013; Tinto, 1993). Social integration explains the degree of students sharing the attitudes and beliefs with their peers, faculty and staff at the institution (Pascarella and Terenzini, 2005; Tinto, 1993; Wolf-Wendel et al., 2009). It refers to the students' perceptions of these interactions, as well as involvement in extra- and co-curricular activities (Tinto, 1993; Wolf-Wendel et al., 2009). Academic integration is used partly to explain the level of adherence to the structural rules and requirements of the institution, i.e. the institutional culture (Pascarella and Terenzini, 2005; Tinto, 1993; Wolf-Wendel et al., 2009). It also refers to perceptions of the experiences in the formal and informal academic system: interactions with staff and students inside and outside the classroom settings that enhance the intellectual development of the student (Tinto, 1993; Wolf-Wendel et al., 2009). Studies show that a higher degree of social and academic integration leads to a higher level of intellectual development, greater quality of effort, enhanced learning, and improved student success (Astin, 1993; Bitzer, 2009; Lacante et al., 2001; Tinto, 1993; Tinto and Pusser, 2006). Since it serves as the foundation of subsequent affiliations and engagements (Tinto and Pusser, 2006), integration is most important for students in their first year at an institution (Wolf-Wendel et al., 2009). 


\section{Models of PAL: peer tutoring versus peer mentoring}

Research shows that PAL provides important opportunities to help new students cope in the first year of university and beyond (Callcott et al., 2014; Lehmann, 2014), as well as providing an important role model for student success (e.g. Pagan and Edwards-Wilson, 2003; Santos and Reigadas, 2002; Goff, 2011; Story, 2013; Makura et al., 2011; Tangwe and Rembe, 2014). PAL can be understood as an umbrella term for various strategies to facilitate learning through active and interactive social engagement among peers (Topping, 2005; Topping and Ehly, 2001). The general trend to implement PAL in higher education was inspired by the social-constructivism learning theory. In this sense, learning is understood as a process that is constructivist, cumulative, self-regulated, purposeful, situated, collaborative and individually different. Collaborative learning, or learning in groups, is justified and stimulated as an effective and efficient learning method. PAL is a classic example of these learning methods of people from a single group helping each other and learning by doing so (Byl et al., 2011). Although PAL emerged as a model based on active learning (Duron et al., 2006) and focused on peer collaborative work (Ning and Downing, 2010), it has now adopted a variety of methods (Roscoe and Chi, 2007), and the role played by peers in the learning process can vary significantly (Loots, 2009). Each PAL format has its own strengths and weaknesses (Maheady et al., 2006; Maheady and Gard, 2010). The most commonly used PAL methodologies are peer tutoring and peer mentoring (Byl et al., 2011). According to Topping (2015, p.2) 'peer tutoring (PT) is characterised by specific role taking as tutor or tutee, with high focus on curriculum content and usually also on clear procedures for interaction, in which participants receive generic and/or specific training'. Peer mentoring (PM) on the other hand can be described as a supportive one-toone relationship with a more experienced student in a common area of interest (Topping and Ehly, 2001; Topping, 2015). PM is mainly organised as cross-age PM and focuses on a group of students at risk (Topping and Ehly, 2001). A large number of PAL methods are institutionally organised and/or academic staff-led and used inside classroom environments with the aim of making students become more active and attached to their peers and their learning tasks. 


\section{Appreciative inquiry}

So far, PAL has been mainly explored by means of quantitative research focusing on learning and academic achievement (e.g. Topping, 2005; Maheady and Gard, 2010; Field et al., 2007). This paper builds upon the significance of PAL to provide opportunities to enhance student integration. However, the goal of our study was to explain the design of the PAL programme which was implemented in 2014 at the Free University of Brussels in order to enhance the effectiveness of support for social and academic integration. As such, a qualitative approach was necessary (Denzin and Lincoln, 2013). We chose the method of Appreciative Inquiry (AI) to identify positive organisational attributes that best supported students' integration. This alternative approach to traditional organizational development models examines organisational issues by discovering what is working particularly well in an organisation, rather than focusing on needs and gaps. In addition, individuals may be more willing to reflect upon what has worked well in their past (Reed, 2006). We believed that Al was more appropriate than other approaches as it enabled students to give direct feedback on the central research topics of this study. Furthermore, it immediately connects negative student experiences to points for improvement.

$\mathrm{Al}$ is a qualitative, participative and interpretive research approach that was developed by Cooperrider and Srivastva (1987), and it challenges the basic assumption that research must be problem-based. In educational sciences, Al is a relatively innovative asset-based approach (Coghlan et al., 2003; Kung et al., 2014). Al is an evaluative mind-set, and is specifically useful in educational evaluative research (Coghlan et al., 2003; Grant and Humphries, 2006; Fergy et al., 2011). As a form of social constructivist evaluation, Al aims to enable people involved in evaluation to make sense of an educational change through dialogue, reflection and interaction. There are four main stages within AI (Figure 1): discovery, dream, design and destiny (Barrett, 1995; Lavender and Chapple, 2004). 


\section{Figure 1. Four main stages within Al.}

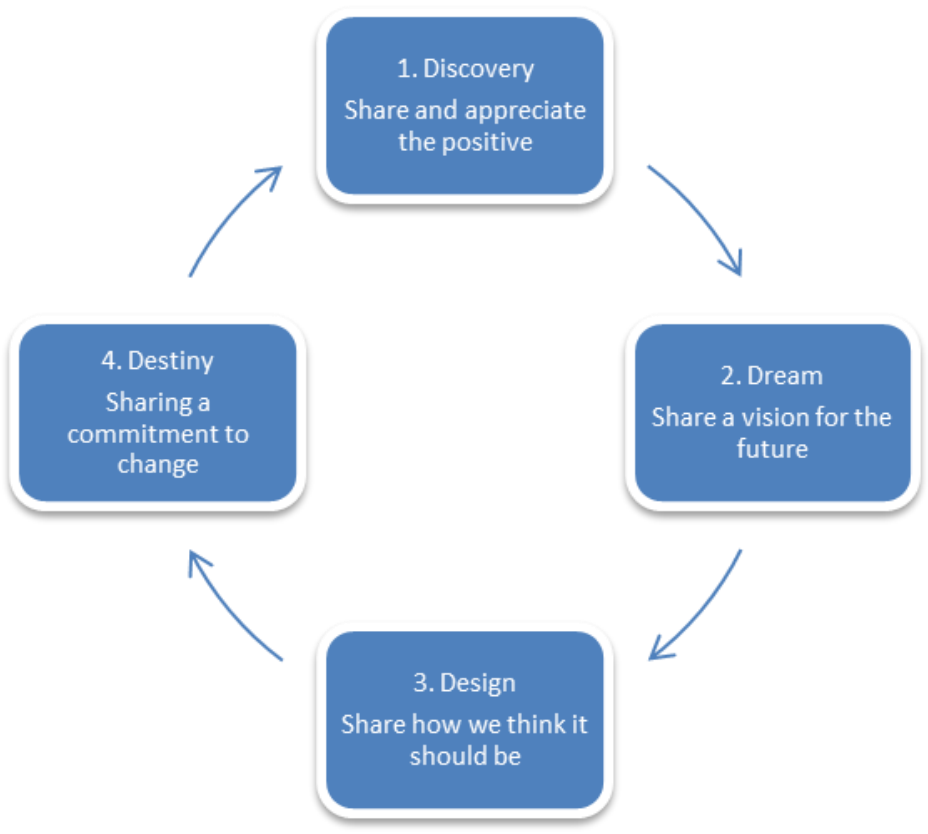

$\mathrm{Al}$ is a strengths-based research approach that focuses on identifying and replicating successes, rather than on identifying and solving problems. In other words, using Al as the framework for evaluation, the first questions to be posed ('discovery') would ask the participants to focus on stories of best practice, positive moments, greatest learning, successful processes and so on, and then to 'dream' about how the system under study could be even better (Watkins and Mohr, 2001). The intention, therefore, is to create an upward, as opposed to downward, spiral. Al differs from other approaches in that it recognises the power of positive language (Czarniawska-Joerges, 1996). Al aspires to capture what is working well in an educational experience, why this is the case, for whom, and how we might translate success in one aspect of an educational endeavour to other aspects of that endeavour (Fergy et al., 2011). In this way, we believed that the data collected using appreciatively oriented questions contributed to a more comprehensive understanding of supportive activities; how these were prioritised as well as how they were perceived by students. In addition, we supposed that Al was more appropriate than other approaches as it affords participants an appreciative lens as a means of understanding the enduring power of educational experiences and energises them to reach for higher ideals in future practices (Giles and Kung, 2010; Kung et al., 2014). 


\section{Research aim and questions}

We opted for an Al method to explore students' views on peer support for social and academic integration. Exploring the experiences, needs and wishes of students may hold the key to discovering and reducing student deficits in satisfaction, adjustment and performance (Rubin and Wright, 2014). The central research question we addressed is the way in which PAL should be designed to optimise the social and academic integration of students.

Hence, we will focus on the following research questions:

- What experiences do students consider successful with regards to peer support in relation to their social and academic integration?

- What are the wishes and needs of students for support from peers regarding social and academic integration?

- What actions need to be taken accordingly, in order for students to promote success socially and academically?

\section{Methodology}

For this study, qualitative data was collected by using the Al method between the spring and autumn of 2013. Focus group interviews were conducted and were considered more appropriate than one-to-one interviews: they have the advantage of generating dialogue around the subject and allow for the identification of variety and difference within 'ordinary opinions' (Lunt and Livingstone, 1996; Lavender and Chapple, 2004).

The research was part of a broader project within the university and was set up to inform the design of the PAL programme which was implemented in 2014. For this purpose, only three of the four main stages of Al were used and contributed to answers or research questions. Once students had made decisions regarding appropriate actions, it was hoped that implementation of them, within the faculty, would be achieved in the PAL programme and the fourth step could then be used. 


\section{Sample}

The sampling strategy and size were determined by the duration and location of the study. All the students who enrolled in the Faculty of Psychology (PSY) and Educational Science (EDWE) in 2012-2013 were asked to participate in focus groups. Only the new students who had no earlier experiences at university and had come directly from secondary school could participate in these focus groups (in Belgium, secondary school takes place after primary education and may be followed by higher education. It provides education for ages 11 to 18). Recruitment was via email and face-to-face in classes. Students could write their names on papers or fill out the online form. In total, 16 separate focus-group interviews were conducted with 93 first-year students and took place on the campus. Participants were informed in advance and confidentiality was guaranteed. Baseline details of participating first-year students were obtained (Table 1).

Table 1. Baseline details of participating first-year students.

\begin{tabular}{|l|c|c|c|c|c|}
\hline \multicolumn{7}{|l|}{ Table 1 } & PSY & EDWE & Men & Woman & Total \\
\hline Group 1 & 0 & 6 & 4 & 2 & 6 \\
\hline Group 2 & 0 & 5 & 0 & 5 & 5 \\
\hline Group 3 & 0 & 3 & 0 & 3 & 3 \\
\hline Group 4 & 4 & 0 & 0 & 4 & 4 \\
Group 5 & 6 & 1 & 0 & 7 & 7 \\
Group 6 & 0 & 8 & 0 & 8 & 8 \\
Group 7 & 1 & 7 & 1 & 7 & 8 \\
Group 8 & 2 & 6 & 1 & 7 & 8 \\
Group 9 & 5 & 1 & 0 & 6 & 6 \\
Group 10 & 2 & 1 & 0 & 3 & 3 \\
Group 11 & 4 & 0 & 0 & 4 & 4 \\
Group 12 & 5 & 1 & 1 & 5 & 6 \\
Group 13 & 2 & 3 & 1 & 4 & 5 \\
Group 14 & 3 & 4 & 1 & 6 & 7 \\
Group 15 & 4 & 1 & 1 & 4 & 5 \\
Group 16 & 5 & 3 & 0 & 8 & 8 \\
\hline Total & 43 & 50 & 10 & $\mathbf{8 3}$ & $\mathbf{9 3}$ \\
\hline
\end{tabular}

\section{Data collection and analysis}

Using the Al method, facilitators invited participants to think about a successful peer support method for integration. At one moment in time, various focus group interviews were conducted, each time taking the participants through the three phases of Al. In a first phase, the interviewer asked for positive memories and experiences of peer support for social and academic integration. In a second phase, participants were asked to be as creative as possible and to think about an ideal image of support for social and academic 
integration. The third phase examined participants' ideas for necessary actions and recommendations about support for social and academic integration. During all phases, the participants were asked to differentiate between three moments in the academic year (first weeks of arrival, one month after arrival, during examination period).

In order to counter the limitations of $\mathrm{Al}$ - to encourage constructive criticism and foster an unwillingness to address weaknesses (Dick, 2004) - and in order to maintain the balance between strengths and weaknesses in the research (Patton, 2003), the questions addressed to the focus groups were open-ended (Figure 2).

In each focus-group interview, both social integration and academic integration were discussed. Starting with a one-minute individual preparation, each phase lasted around ten minutes. After circa 40 minutes, participants got a 15-minute break before starting the second theme.

\section{Discovery}

- What experiences related to peer support do you find successful and what was working well for your social/academic integration and why?

\section{Dream}

- How would you describe the ideal future scenario of peer support for your social/academic integration? How would you conceive permanent peer support?

\section{Design}

- What actions need to be taken? What should be our principles? How can we make this happen?

Figure 2. Interview questions based on the first three stages within Al.

The students made notes before the focus group and verbatim quotes of frequently occurring issues were documented throughout the process. In this way, everyone had a foothold during the interview and the interviewer could dig deeper into the judgements of students. 
Focus group interviews lasted between 120 and 200 minutes, driven by the students, and were tape-recorded. Complete verbatim transcripts were made by three researchers. Focus group data were all conjointly analysed by two researchers. The phases were analysed separately. Inter-rate reliability exceeded $90 \%$ and discussions took place to ensure a consensus was reached in all cases.

\section{Results}

The results will be presented according to the various themes identified in this research and related to the support and timeframe in which they appear: first four weeks after arrival, after one month, and during the last four weeks (Figure 3). Focus groups were conducted in the second semester and participants were questioned on their first semester experiences. Following the principles of $\mathrm{Al}$, the results are related to good examples of support from peers and to the needs and wishes of students for support in social and academic integration. These needs and wishes will be presented in relation to the timeframe in which they existed in the form of the action design, which is the third phase of Al. A summary of the main themes that emerged in Phase 1 is presented in Figure 3. These themes refer to the various peer support schemes available to students.

\begin{tabular}{|c|c|c|c|}
\hline & First four weeks & After one month & Last four weeks \\
\hline $\begin{array}{c}\text { Academic } \\
\text { integration }\end{array}$ & & Buddy scheme & Student organisation \\
\hline $\begin{array}{c}\text { Social } \\
\text { integration }\end{array}$ & Student ambassadors & & \\
\hline
\end{tabular}

Figure 3. Identified themes related to the timeframe and support for integration.

\section{Student ambassadors: support for social integration during the first weeks}

During their first weeks at university, all the participants were questioned about their appreciation of the support they experienced. $64 \%$ of the participants $(\mathrm{N}=60)$ stated their satisfaction with their experiences with student ambassadors in relation to social integration. University student ambassadors are current students who help 'the university recruiting unit' to promote university life and student life to prospective students and their 
families. Student ambassadors mainly help with campus tours at the main Open Days in June, September and October. They indicated that student ambassadors specifically helped them with finding their way on campus and stated that they were more likely to discuss problems with these students because they were in the same position. They also referred to the characteristics of the role of the student ambassador. $16 \%$ of the participants $(\mathrm{N}=15)$ believed that they felt confident to ask questions because of the meet and greet with student ambassadors during their visit to one of the University Open Campus Days before they arrived. The student ambassadors' (as a type of facilitator) 'open minded' attitude when guiding students on campus was considered significantly welcome:

I went to them with the dumbest questions...At the University's Open Day it was also the same; you could ask them about really everything. (Student 7: first-year student - EDWE)

Facilitators became a familiar face. Consequently, this helped to reduce barriers of personal anxiety and allowed students not to feel shy. Most students felt that student ambassadors were considered as a good source of personal informational support, because of their enthusiasm, their friendly faces and their support and open-mindedness:

I think it might be easier to ask questions if you already know each other. As such, the threshold is even lower. (Student 9: first-year student - EDWE)

According to $27 \%$ of the participants $(\mathrm{N}=25)$, the strongest features were providing information and answering queries in terms of academic and non-academic problems. Moreover, the fact that student ambassadors answer questions, both face-to-face and through Facebook, and are always available to help someone, contributed significantly to a sense of belonging from the beginning:

Actually it's very convenient that you can have contact with her (student ambassador) through Facebook. You don't know her, but you can just send messages and she answers very quickly. She really does take her time. (Student 7: first year student - EDWE) 
The frequency with which student ambassadors were present on campus and, how they set up a help desk (online Facebook group) for new students of the faculty, was considered very valuable. Some students reported that this encouraged them to be more engaged and to participate in activities:

In the beginning I had asked many questions to our student ambassadors. And then, actually I felt very involved. (Student 8: first-year student - EDWE)

Following on from the experiences of support during the first weeks of arrival, we can conclude that $64 \%$ of the participants $(\mathrm{N}=60)$ indicated a satisfaction about support with regards to social integration. Furthermore, $73 \%$ of the participants ( $N=68$ ) expressed many needs and wishes that pointed to the importance of combining social support with academic support initiatives. A summary of main action points that emerged in phase 2 and phase 3 is presented in the following box:

\section{Student action design:}

- Organising official student advocate schemes, including needed personal, social and academic support.

- Supported by training.

- Ensuring opportunities to ask questions face-to-face and on a virtual level.

- Ensuring guidance in the system, organisation and environment of the university, faculty and department.

\section{Buddy scheme: support for social and academic integration after one month}

All participants were questioned about their satisfaction regarding the support from peers after the first weeks at the university. Positive experiences with peers mainly related to forms of social and personal support and were linked mostly to their social integration. These experiences were generally expressed in terms of making friends and feeling connected with fellow university students and students feeling more at home at the university: 
She helped me to know the area and have some friends. I felt more at ease. I was not stressed anymore. Yes, slowly...she made me feel at home. (Student 83: firstyear student - PSY)

The buddy scheme is organised by the faculty student organisation (informal) and can be described as a supportive one-to-one relationship between a first year student and an experienced student. Buddies are enthusiastic volunteering members of the faculty student organisation who help first year students to settle into the university. During the first semester, $31 \%$ of the participants $(\mathrm{N}=29)$ reported to have a buddy provided by the faculty student organisation. They were satisfied with the buddy scheme organised by the student organisation. In this regard, $16 \%$ of the participants $(\mathrm{N}=15)$ talked about their trip to the centre of the city and were pleased with the outcome of various games to enable them to get to know different buddy candidates. It 'facilitated the choice of a buddy' (higher-year student). They showed great appreciation for activities, which made the buddy choice easier. Some of them claimed that these meet and greet activities, as well as meetings outside the university context, increase personal contact and understanding with the mentor:

We have also agreed to go out in the evening or to do an activity together outside the university context. This is important to actually get to know people, without social media. (Student 8: first-year student - EDWE)

The impact of the buddy scheme is generally expressed in terms of help in settling in, dealing with a new environment and city, and making friends with other fellow students and buddies, i.e. bonding/bridging and getting involved with student communities. Students really appreciated other students asking them to participate in activities. This kind of companionship is considered to be the best feature of the buddy scheme:

The idea that you have someone provides a context in which you do not have to feel lonely. Someone who takes care of people and introduces you to new people and networks. In the beginning you simply do not reach out to others. (Student 8: first-year - EDWE)

The strongest feature, according to $78 \%$ of the participants $(\mathrm{N}=73)$, was the one-to-one relationship with a more experienced student, who answers questions and shares 
knowledge and experiences. Moreover, the idea that these experienced students are almost always available to help with academic and non-academic problems, face-to-face as well as by virtual communication (sms or call or social media), is considered very valuable:

When you encounter them on campus, knowing them and being able to ask questions. You can always request information, but it does give a better feeling when you know each other. (Student 9: first-year - EDWE)

\section{Student action design:}

- Organising a mentoring scheme, which is voluntary but requires a commitment.

- Guarantee initiatives, which are open to all students, and combine personal, social and academic support during the entire year.

\section{Student organisations: support for academic integration during the last four weeks}

$25 \%$ of the participants $(\mathrm{N}=23$ ) believed the student organisation is similar to the buddy scheme and experienced this as a good way of personal mentoring support; including engagement in both a formal and informal way, learning support, learning study skills, and answering questions. During the exams, $17 \%$ of the participants $(\mathrm{N}=16)$ referred to the importance of the faculty student organisation in terms of encouragement, reducing stress and reducing personal anxiety. They took heart from this, so they didn't lose courage:

During the exams, if I had a stressful moment, I could always call her or send text messages on that subject, and ask for example 'What is important?'. Because I was stressed for time. [Student 52: first-year - PSY]

$53 \%$ of the participants $(\mathrm{N}=50)$ reported their appreciation for the initiative offered by two members of the faculty student organisation who worked together in one class. It increased their feeling of academic integration. The impact of this group tutoring initiative is generally expressed as examination support, which created confidence about exams or gave faith in exams again: 
You'll feel much more confident then, when you know what to do and exactly how to do it. Otherwise, you are on your own. [Student 55: first-year - PSY]

Positive experiences with peers in the last weeks of lectures were linked mostly to their academic integration. $78 \%$ of the participants $(\mathrm{N}=73)$ believed that experienced higheryear students, who provide tips and tricks about coursework or exams, share their knowledge and experiences about the best practices to prepare and learn for exams, or provide notes and summaries, are good examples of the instrumental support (examination support and content specific support). Indeed, a lot of them also seem to benefit from studying together with classmates.

\section{Student action design:}

- Organising cross-age two-to-one group tutoring schemes for examination support (e.g. difficult subject matter) and one-to-one counselling for last minute help.

- Organising same-age/year tutoring schemes in public places, such as the library, to study for exams in peer groups.

\section{Discussion}

The present study explored the potential of PAL as a tool for student integration in the first semester at university. We used the method of Al to address our research question: how should PAL be designed to optimise the social and academic integration of students? It can be concluded that spontaneous support initiatives in an informal learning environment are highly desirable (e.g. student ambassadors, buddy scheme, membership in student organisations) and that integration can be improved by providing formal and structural support. Participants suggested that peer support needs to be independent of individual differences in providing support and should be organised by neutral institutional management in order to increase accessibility and equal support for the whole group of students (e.g. not every student holds a student organisation membership). In this respect, when addressing some specific criteria related to the objectives and form and design, this paper suggests that PAL is particularly useful during the first semester in increasing integration among students. 


\section{Defining PAL objectives for student integration}

Participants expressed their ideas about PAL as a tool to enhance and support social and academic integration. Results show the importance of peer learning schemes, which take into account one-to-one relationships. Zacharopoulou and Turner (2013, p.49) and Van der Meulen et al. (2005) state that individual peer assistance is crucial to support first-year students. First-year students feel relieved because there is always someone with knowledge and experience close by (Austin and Hatt, 2005). Indeed, Richardson and Tate (2013) argue that it is important for students to be able to approach these higher-year students to ask formal and informal questions. Although both knowledge and experience is important, our study clearly shows that students need someone who takes responsibility on the one hand for informational (formal) support and on the other hand someone for emotional and mental (informal) support.

Participants emphasised the importance of the attitude of higher-year students and their relationship with them. Higher-year students were friendly and provided one-on-one consultation (Tangwe and Rembe, 2014). Frequent encounters, visibility and pro-activity were highly valued, including both face-to-face and online communication (Leck and Wood, 2013). Furthermore, 'recognisability' as well as 'good and open behaviour' were claimed to be important. People should come from the same disciplines or departments (Tangwe and Rembe, 2014) and should be introduced as early as possible and be presented to the people who can support their learning (Court and Molesworth, 2008). Our study suggests that peer facilitators from the same discipline or departments gain more credibility in offering informational support and instructional support than peer facilitators from other disciplines. The more specific the informational or instructional support, the more credibility is needed. For emotional or companion support, trust and friendship is more important. In this way, our study shows that the interpersonal qualities are key to peer relationships and experiencing the benefits of peer support in an informal context. Students particularly value a setting that facilitates the choice of a mentor. They need time to know if there is friendship possible.

Participants claimed the need for a peer facilitator, in which each initiative combines an academic as well as a social dimension. The importance of developing the capacity of students to engage effectively in their higher education experiences across all spheres of institutional activity is also highlighted by Thomas $(2011 ; 2012)$. The social and academic dimension is considered to be an indispensable factor, in respect to student satisfaction on 
the one hand and learning anxiety on the other (Shim and Ryan, 2012; Longden and Yorke, 2009). As in Lamb et al. (2013) and also highlighted by Risquez and SanchezGarcia (2012), they found that peer facilitators created an intimate atmosphere and space for first-year students that generated a place for reflection and feedback within this relationship. Moreels (2005) and Van der Meulen et al. (2005) show that peer facilitators also encouraged making new friends and networking, which is consistent with our results. Our results can contribute to this literature by showing the expectations of each of the facilitators concerning support for social integration. Peer facilitators providing information support or instruction support can enhance social integration by organising this in small face-to-face and online groups. Peer facilitators providing emotional support or esteem support can enhance this by slowly introducing individuals to other individuals and groups to build a network in both the virtual and the real world.

Our study showed multiple arguments for prolonged and continuous support during the whole semester and the first year. Obviously, participants point out that the effectiveness of supportive activities is related to various timeframes: the period of arrival, the period of learning and the period of examination (Figure 4).

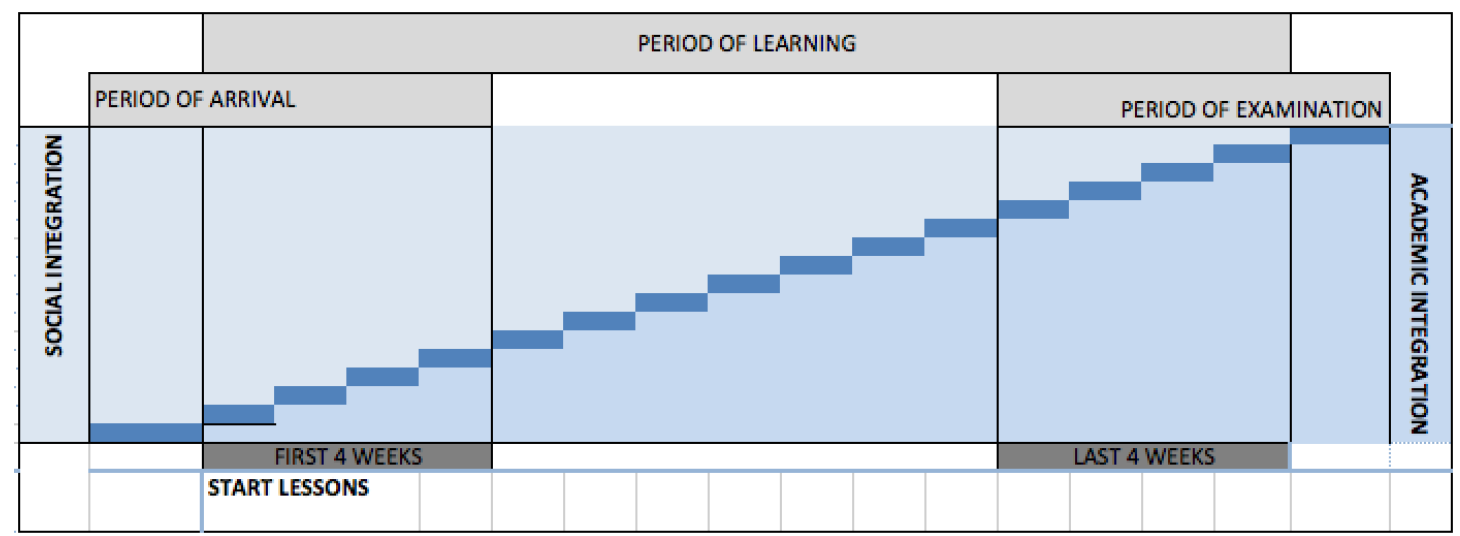

Figure 4. Integration-PAL support model.

Participants claimed that initially, peer facilitators should have a larger focus on the social dimension, and then, during the second half of the semester, they should focus more strongly on the academic dimension. Our study suggests that if PAL were to be conceived as a tool for integration, it would need to adopt a broader timeline than a traditional PAL: ideally, it should commence before the academic year starts and should continue during the examination period. 


\section{Form and design of PAL for student integration}

Participants indicated the importance of an adequate form and design of activities and initiatives. They needed to include academic and social, as well as personal support. Each peer-role had its own value, also related to various timeframes. In the results section, participants referred on the one hand to the value of the buddy system as a form of mentoring during the learning period (Loots, 2009). They referred to the importance of a personal guide, who initially brought more emotional, mental and personal support, and secondly more social and academic support. They brought companionship and esteem support first of all (Miller et al., 2010; Hamshire et al., 2015), then informational and instructional support.

On the other hand, participants also refer to the value of student ambassadors (with the campus tour and helpdesk) as a form of mentoring during the period of arrival and the period of examination (Potter and Hampton, 2009; Hilsdon, 2014) - see Figure 4. They refer to the importance of a personal guide, who primarily brought academic and social support, and additional personal support. They brought mainly informational support (Callcott et al., 2014; Parkes, 2014). In general, the impact of these student ambassadors was strong because they provided 'hot knowledge', providing students with the opportunity to experience the campus and university (Walker et al., 2004; Parkes, 2014). They had gained enough experience on campus to be a role model and there was not much age difference with first-year students (Austin and Hatt, 2005). This is confirmed by Donche et al. (2010), who affirm that more experienced students can assess what learning methods should be adopted more adequately. It has been suggested that student ambassadors must be student advocates and have specific experiences related to the knowledge students need (e.g. Gorard and Smith, 2007; Parkes, 2014). Concerning this, it was important that the same accessibility exists as with mentors (Fox and Stevenson, 2006).

Concerning tutoring, participants suggested that the period of learning initiatives should be focused on awareness and mental support (informally addressed), and should have less focus on learning, as the understanding of what studying entails and what students need is not yet recognised by them (Callcott et al., 2014). For example, regarding difficult courses, in the first semester cross-age tutoring is more important in providing last minute help when students notice their own boundaries, instead of providing preventative measures, as awareness of the need for these measures does not exist yet. For example, awareness only exists when the students start planning for assessments or start studying for 
challenging courses, such as statistics, based on an underlying performance anxiety. However, this research suggests that emphasis should be placed on modelling, instead of on tutoring. According to Topping and Ehly (2001), [peer modelling] should provide an example of desired learning behaviour by someone in the peer group, with the aim that the others in the group would follow suit and comply. According to the participants, this would encourage success stories, for example, about a student's study schedule. Where modelling focuses on success stories, tutoring focuses on problem solving (Topping, 2015).

\section{Limitations and further research}

There are several limitations to the present study. Firstly, it should be noted that this study explores student experiences with peer-learning schemes (e.g. tutoring and mentoring) in an informal educational context. Future research should explore other forms of peerlearning approaches to promote social and academic integration. Secondly, this study focused on new students coming directly from secondary school. If we are to meet the challenges of the increasingly diverse student population and improve the quality of all students' learning experience, particularly in the first year of study, we need to explore the experiences of other types of students (e.g. transfer students, working students) (Altbach et al., 2009).

Additionally, it would be beneficial to agree on the definitions and specific features of peer support and peer learning, in such a way that there is a common language for scholars, institutional researchers and practitioners (Davidson and Wilson, 2013). For instance, participants in this study preferred to form peer groups (i.e. same age tutoring) and study their exams in public places, such as a library. Investigating why this enhances their integration and how this occurs would be interesting for the further development and validation of PAL.

In conclusion, we recommend future research on forms of peer learning to include both qualitative inquiries and quantitative research studies. It is important to devise meaningful, qualitative questions that will complement a quantitative survey evaluation instrument. We believe Al can be a valuable and promising tool for the further development of PAL programmes, as a means to improve its value for the social and academic integration of 
students. However, in order to counter the disadvantages of focus group interviews - the lack of in depth individual replies - further understanding of peer learning programmes for social and academic integration needs to be addressed by individual interviews.

\section{Conclusion}

This qualitative research has contributed to the literature by showing that during the first semester of the academic year, both face-to-face and online PAL methods are important for the development of integration among students. Peer mentoring and peer modelling are specifically important and have their own value and function. Peer modelling primarily functions as an informant (they know) and a peer mentor primarily functions as a companion (they will). As our results suggested, the better the relationship in terms of friendship, the more emotional and esteem support they perceive themselves to receive. This paper suggested that the interpersonal qualities and the creation of a setting which facilitates the choice of a mentor are key to peer relationships and to experiencing the benefits of peer support in an informal context. However, peer tutoring that is spontaneous and informally organised with friends or classmates is more likely to increase the participation of students. In this sense, the peer tutor can be considered as an instructor (they can). This research indicates that combining PAL with the promotion of social integration as early as possible only requires a small investment, while generating a large additional value for their academic integration. In this sense, this article hopes to have demonstrated the merits of PAL for promoting academic as well as social integration.

\section{References}

Altbach, P., Reisberg, L. and Rumbley, L. (2009) Trends in global higher education: tracking an academic revolution. A report prepared for the UNESCO 2009 world conference on higher education. Paris: The United Nations Educational, Scientific and Cultural Organisation.

Astin, A.W. (1993) What matters in college? Four critical years revisited. San Francisco: Calif Jossey-Bass 
Austin, M. and Hatt, S. (2005) 'The messengers are the message: a study of the effects of employing higher education student ambassadors to work with school students', Widening Participation and Lifelong Learning, 7(1), pp. 1-8.

Barrett, F.J. (1995) 'Creating appreciative learning cultures', Organizational Dynamics, 24(2), pp. 36-49.

Bitzer, E.M. (2009) 'Academic and social integration in three first-year groups : a holistic perspective', South African Journal of Higher Education, 23(2), pp. 225-245.

Borglum, K. and Kubala, T. (2000) 'Academic and social integration of community college students: a case study', Community College Journal of Research and Practice, 24(7), pp. 567-576.

Brown, K., Nairn, K., Van Der Meer, J. and Scott, C. (2014) 'We were told we're not teachers...it gets difficult to draw the line: negotiating roles in peer-assisted study sessions (pass)', Mentoring \& Tutoring: Partnership in Learning, 22(2), pp. 146-161.

Byl, E., Struyven, K., Van Roosmalen, G., Berghmans, I., Vierendeels, R., Brants, L. and Lombaerts, K. (2011) 'Peer assisted learning implementeren in het hoger onderwijs', Tijdschrift Voor Hoger Onderwijs, 32(4), pp. 205-223.

Callcott, D., Knaus, M., Warren, J. and Wenban, A. (2014) 'Network Teach: how a student led organisation supports the transition to university', Australian Journal of Teacher Education, 39(8), pp. 1-13.

Coghlan, A.T., Preskill, H. and Tzavaras Catsambas, T. (2003) 'An overview of appreciative inquiry in evaluation', New Directions for Evaluation, 2003(100), pp. 522.

Cooperrider, D.L. and Srivastva, S. (1987) 'Appreciative inquiry in organizational life', Research in Organizational Change and Development, Vol. 1, pp. 129-169. 
Court, S. and Molesworth, M. (2008) 'Course-specific learning in peer assisted learning schemes: a case study of creative media production courses', Research in PostCompulsory Education, 13(1), pp. 123-134.

Czarniawska-Joerges, B. (1996) 'Realities and relationships', in Gergen, J. (eds.)

Soundings in social construction. Cambridge, MA: Harvard University Press, p. 356.

Davidson, C. and Wilson, K. (2013) 'Reassessing Tinto's concepts of social and academic integration in student retention', Journal of College Student Retention: Research, Theory \& Practice, 15(3), pp. 329-346.

Denzin, N.K. and Lincoln, Y.S. (2013) Strategies of qualitative inquiry. USA: Thousand Oaks Sage.

Dick, B. (2004) 'Action research literature', Action Research, 2(4), pp. 425-444.

Donche, V., Coertjens, L. and Van Petegem, P. (2010) 'Learning pattern development throughout higher education: A longitudinal study', Learning and Individual Differences, 20(3), pp. 256-259.

Duron, R., Limbach, B. and Waugh, W. (2006) 'Critical thinking framework for any discipline', International Journal of Teaching and Learning in Higher Education, 17(2), pp. 160-166.

Fergy, S., Marks-Maran, D., Ooms, A., Shapcott, J. and Burke, L. (2011) 'Promoting social and academic integration into higher education by first-year student nurses: the APPL project', Journal of Further and Higher Education, 35(1), pp. 107-130.

Field, M., Burke, J.M., Mcallister, D. and Lloyd, D.M. (2007) 'Peer-assisted learning: a novel approach to clinical skills learning for medical students', Medical Education, 41(4), pp. 411-418.

Fox, A. and Stevenson, L. (2006) 'Exploring the effectiveness of peer mentoring of accounting and finance students in higher education', Accounting Education, 15(2), pp. 189-202. 
Giles, D. and Kung, S. (2010) 'Using appreciative inquiry to explore the professional practice of a lecturer in higher education: moving towards life-centric practice', Australian Journal of Adult Learning, 50(2), pp. 308-322.

Goff, L. (2011) 'Evaluating the outcomes of a peer-mentoring program for students transitioning to postsecondary education', The Canadian Journal for the Scholarship of Teaching and Learning, 2(2), pp. 1-13.

Gorard, S. and Smith, E. (2007) 'Beyond the 'learning society': what have we learnt from widening participation research?', International Journal of Lifelong Education, 25(6), pp. 575-594.

Grant, S. and Humphries, M. (2006) 'Critical evaluation of appreciative inquiry: bridging an apparent paradox', Action Research, 4(4), pp. 401-418.

Hamshire, C., Jack, K., Prowse, A. and Wibberley, C. (2015) 'Maria's story - the narrative of a mature international student', Journal of Learning Development in Higher Education, Issue 8, March, pp. 1-14. [Online]. Available at: http://www.aldinhe.ac.uk/ojs/index.php?journal=jldhe\&page=article\&op=view\&path \%5B\%5D=219 (Accessed: 26 June 2015).

Hilsdon, J. (2014) 'Peer learning for change in higher education', Innovations in Education and Teaching International, $51(3)$, pp. 244-254.

Kung, S., Giles, D. and Hagan, B. (2014) 'Applying an appreciative inquiry process to a course evaluation in higher education', International Journal of Teaching and Learning in Higher Education, 25(1), pp. 29-37.

Lacante, M., De Metsenaere, M., Lens, W., Van Esbroeck, R., De Jaeger, K., De Coninck, T. and Santy, L. (2001) Drop-out in hoger onderwijs: onderzoek naar achtergronden en motieven van drop-out in het eerste jaar hoger onderwijs. Leuven: KULDepartement psychologie. 
Lamb, P., Lane, K. and Aldous, D. (2013) 'Enhancing the spaces of reflection: a buddy peer-review process within physical education initial teacher education', European Physical Education Review, 19(1), pp. 21-38.

Lavender, T. and Chapple, J. (2004) 'An exploration of midwives' views of the current system of maternity care in England', Midwifery, 20(4), pp. 324-334.

Leck, J. and Wood, P. (2013) 'Forming trust in e-mentoring: a research agenda', American Journal of Industrial and Business Management, 3(1), pp. 101-109.

Lehmann, W. (2014) 'Habitus transformation and hidden injuries: successful working-class university students', Sociology of Education, 87(1), pp. 1-15.

Longden, B. and Yorke, M. (2009) 'Institutional research: what problems are we trying to solve?', Perspectives: Policy and Practice in Higher Education, 13(3), pp. 66-70.

Loots, D.A. (2009) 'Student involvement and retention in higher education: the case for academic peer mentoring programmes for first-years', Education as Change, 13(1), pp. 211-235.

Lunt, P. and Livingstone, S. (1996) Rethinking the focus group in media and communications research. London: LSE Research Online. Available at: http://eprints.Ise.ac.uk/archive/00000409. (Accessed: 1 July 2015).

Maheady, L. and Gard, J. (2010) 'Classwide peer tutoring: practice, theory, research, and personal narrative', Intervention in School and Clinic, 46(2), pp. 71-78.

Maheady, L., Mallette, B. and Harper, G.F. (2006) 'Four classwide peer tutoring models: similarities, differences, and implications for research and practice', Reading \& Writing Quarterly, 22(1), pp. 65-89.

Makura, A., Skead, M. and Nhundu, K. (2011) 'Academic development practices at Fort Hare University: an epitome of university access', Research in Higher Education Journal, Vol. 12, pp. 13-22. 
Miller, D., Topping, K. and Thurston, A. (2010) 'Peer tutoring in reading: the effects of role and organization on two dimensions of self-esteem', British Journal of Educational Psychology, 80(3), pp. 417-433.

Moreels, A. (2005) Welkom: het onthaal van nieuwe medewerkers. Mechelen: Kluwer uitgevers.

Ning, H.K. and Downing, K. (2010) 'The impact of supplemental instruction on learning competence and academic performance', Studies in Higher Education, 35(8), pp. 921-939.

Pagan, R. and Edwards-Wilson, R. (2003) 'A mentoring program for remedial students', Journal of College Student Retention, 4(3), pp. 207-226.

Parkes, S. (2014) 'Fostering a sense of belonging: supporting the early formation of student identity as successful learners in higher education', Journal of Learning Development in Higher Education, Issue 7, June, pp. 1-22. [Online]. Available at: http://www.aldinhe.ac.uk/ojs/index.php?journal=jldhe\&page=article\&op=view\&path \%5B\%5D=229 (Accessed: 26 June 2015).

Pascarella, E.T. and Terenzini, P.T. (2005) 'How college affects students (vol. 2): a third decade of research (review)', Journal of College Student Development, 47(5), pp. 589-592.

Patton, M.Q. (2003) 'Inquiry into appreciative evaluation', New directions for evaluation, 100(2003), pp. 85-99.

Potter, J., and Hampton, D. (and Staff and Education Development Association) (2009) Students supporting students. Available at: http://capitadiscovery.co.uk/northumbria-ac/items/1505341 (Accessed: 30 June 2015).

Reed, J. (2006) Appreciative inquiry: research for change. Thousand Oaks, CA: Sage Publications. 
Richardson, M.J. and Tate, S. (2013) 'Improving the transition to university: introducing student voices into the formal induction process for new geography undergraduates', Journal of Geography in Higher Education, 37(4), pp. 611-618.

Risquez, A. and Sanchez-Garcia, M. (2012) 'The jury is still out: psychoemotional support in peer e-mentoring for transition to university', The Internet and Higher Education, 15(3), pp. 213-221.

Roscoe, R.D. and Chi, M.T.H. (2007) 'Understanding tutor learning: knowledge-building and knowledge-telling in peer tutors' explanations and questions', Review of Educational Research, 77(4), pp. 534-574.

Rubin, M. and Wright, C.L. (2014) 'Age differences explain social class differences in students' friendship at university: implications for transition and retention', Higher Education, pp. 1-13.

Santos, S.J. and Reigadas, E.T. (2002) 'Latinos in higher education: an evaluation of a university faculty mentoring program', Journal of Hispanic Higher Education, 1(1), pp. $40-50$.

Shim, S.S. and Ryan, A.M. (2012) 'What do students want socially when they arrive at college? Implications of social achievement goals for social behaviors and adjustment during the first semester of college', Motivation and Emotion, 36(4), pp. 504-515.

Story, C.N. (2013) The relationship of undergraduate first-time-in-college students' expectations of interactions with faculty and four-year college degree completion. Florida: Scholar Commons.

Tangwe, M.N. and Rembe, M.N. (2014) 'The perceptions of students on the implementation of peer academic support programmes at one university in South Africa', Mediterranean Journal of Social Sciences, 5(4), pp. 378-389. 
Thomas, L. (2011) 'Do pre-entry interventions such as 'Aimhigher' impact on student retention and success?', A Review of the Literature. Higher Education Quarterly, 65(3), pp. 230-250.

Thomas, L. (2012) Building student engagement and belonging in higher education at a time of change: final report from the 'What works? Student Retention \& Success Programme'. London: Paul Hamlyn Foundation [Online]. Available at: https://www.heacademy.ac.uk/sites/default/files/what works final report 0.pdf (Accessed: 26 June 2015).

Tinto, V. (1993) Leaving college: rethinking the causes and cures of student attrition. $2^{\text {nd }}$ edn. Chicago: University of Chicago Press.

Tinto, V. and Pusser, B. (2006) 'Moving from theory to action: building a model of institutional action for student success', in Seidman, A. (eds.) College student retention: formula for student success. Westport, CT: ACE/Praeger, pp. 1-51.

Topping, K. (2005) 'Trends in peer learning', Educational Psychology, 25(6), pp. 631-645.

Topping, K. (2015) 'Peer tutoring: old method, new developments/Tutoría entre iguales: método antiguo, nuevos avances', Infancia Y Aprendizaje, 38(1), pp. 1-29.

Topping, K.J. and Ehly, S.W. (2001) 'Peer assisted learning: a framework for consultation', Journal of Educational and Psychological Consultation, 12(2), pp. 113-132.

Van der Meulen, B.F., Vlaskamp, C. and Van den Bos, K.P. (2005) Interventies in de orthopedagogiek. Rotterdam: Lemniscaat.

Walker, L., Matthew, B. and Black, F. (2004) 'Widening access and student non-completion: an inevitable link? Evaluating the effects of the Top-Up Programme on student completion', International Journal of Lifelong Education, 23(1), pp. 4359.

Watkins, J.M. and Mohr, B.J. (2001) Appreciative inquiry: change at the speed of imagination. San Francisco: Jossey-Bass/Pfeiffer. 
Wolf-Wendel, L., Ward, K. and Kinzie, J. (2009) 'A tangled web of terms: the overlap and unique contribution of involvement, engagement, and integration to understanding college student success', Journal of College Student Development, 50(4), pp. 407428.

Zacharopoulou, A. and Turner, C. (2013) 'Peer assisted learning and the creation of a learning community for first year law students', The Law Teacher, 47(2), pp. $192-$ 214.

\section{Author details}

Emmeline Byl is a PhD Researcher in the department of Educational Sciences at Vrije Universiteit Brussel. She is project coordinator for a peer assisted learning programme (PAL) in the Faculty of Psychology and Educational Sciences. Her research interests include social integration, academic integration, peer assisted learning, institutional commitment, and student success in higher education.

Katrien Struyven is Assistant Professor at Brussels' VUB (Vrije Universiteit Brussel) in the Educational Sciences Department. Her research focuses on student-activating and cooperative teaching methods and new modes of assessment in higher education, and teacher education in particular. She teaches introductory and advanced courses on Teaching and Assessment within the Bachelor-Master programme of (Adult) Educational Sciences and within the Academic Teacher Training Programme.

Pieter Meurs holds an MA in Educational Sciences and an MA and PhD in Philosophy and Moral Sciences (Free University Brussels). He has presented and published papers on (post-) phenomenology, critical theory and contemporary political philosophy. He has written extensively on Maurice Merleau-Ponty and Jean-Luc Nancy. His current research focuses on the philosophy of globalisation, myth and worldviews, and he has a specific interest in peer assisted learning.

Bieke Abelshausen is a PhD student in Educational Sciences of the Vrije Universiteit Brussel in Belgium. Her research interests are framed within informal learning with stakeholders from different settings and backgrounds in the frame of community 
development. Her research and teaching experiences focus on sustainable educational practices.

Koen Lombaerts is Head of the Department of Educational Sciences of the Vrije Universiteit Brussel (VUB) and Chairman of the Alliance Research Group VUB-UGhent 'Innovation, Diversity and Educational Approaches' (IDEA). His teaching and research focus on change and innovation in education and lifelong learning with a specific interest in self-regulated learning environments.

Nadine Engels is Professor of Educational Sciences and Teacher Education at the Vrije Universiteit Brussel. Her main domains of research are social affective components of learning and teaching, and professional development of teachers in teacher education and throughout their careers. Recently the focus has been on inquiry-based collaborative learning and on (cultural and structural) conditions for professional learning in the organisational environment.

Tom Vanwing is a full time Professor at the University of Brussels, Department of (Adult) Educational Sciences. He teaches (amongst others): Management for educational change; Sustainable development; Community development; Technology innovations and transfer in third world countries. His research concerns adult education: synergies of combining formal and informal learning; professionalisation and professional roles; and innovative approaches. 